\title{
Enhancing Service Quality to Increase Customer Satisfaction: A Phenomenological Method of Low Cost Carrier Airlines Companies in Indonesia
}

\author{
Resista Vikaliana, Yuli Evitha
}

\begin{abstract}
The air transportation service industry sector is growing rapidly in Indonesia. Various strategies are done by airlines. However, there are also various problems that impact on the decline in quality of service resulting in the decreased customer satisfaction. The research is carried out to know what the problems and challenges faced on service quality (SERVQUAL) in Low Cost Carrier (LCC) Airlines Companies. In-depth interviews were employed in this study, also the questionnaires to triangulate the instruments. The research proved that the Low Cost Carrier (LCC) Airlines Companies still need a lot of improvements for the sake of comfort and safety.
\end{abstract}

Index Terms: Service Quality; Customer Satisfaction; Low Cost Carrier (LCC)

\section{INTRODUCTION}

In the present worldwide focused condition conveying quality administration is considered as a basic system for progress and survival (P30arasuraman et al., 1985; Reichheld and Sasser, 1990; Zeithaml et al., 1990). Administrations are progressively turning into a bigger bit of numerous associations' provincially, broadly, and all around and are considered as a device for income streams. The present learning serious administrations organizations require dependable strategies for estimation, appraisal, and improvement (Spohrer and Maglio, 2008). Different things are found in the service industry sector, where the need for dynamic interaction causes the role of the workforce is still the main thing because the role until now can not be replaced by technology (Layton and Moore 1989). Therefore how well the quality of service is still dependent on the quality of its human resources.

Dadkhah (2009) cited in Alipour and Mohammadi (2011) states that service quality is one of the most important topics in the field of services management and marketing. Nowadays, treating customers with respect is the main organizational activity and a necessity to their existence. Organizations cannot contact with the customers unless they

Revised Manuscript Received on September 22, 2019. Sosial dan Manajemen Stiami, Jakarta, 10530, Indonesia , resistav31@gmail.com

Yuli Evitha, Department Logistics Management, Institut Ilmu Sosial dan Manajemen Stiami, Jakarta, 10530, Indonesia.
Resista Vikaliana,: Department Logistics Management, Institut Ilmu

understand them, and perceive their values, and know that what kinds of services are useful for them, and how or when they intend to make interactional contacts, and they prefer to buy which goods or services.

Service quality is as one of the critical structures to clarify and legitimize conduct targets identified with future and the ideal impacts on the monetary outcomes and results of organization and service quality is as one of the key procedures for the survival of an organization that have analyzed and assessed it and thinking about significance of service quality, there's no big surprise that numerous analysts have committed themselves to understanding the components of service quality (Gilaninia and et al, 2013).

Because of the expanding job of service quality associations in the regions of the economy and the significance of value in the territories of rivalry, service associations must hope to support service quality with dynamic and vital methodology and have an unmistakable comprehension of the quality status of service, the desires for the customer (client) and the general attributes of their quality (Nejadjavad and Gilaninia, 2016).

Many companies are already aware of the importance of good service to consumers as one form of responsibility, because good service will have a positive impact on customer satisfaction. But sometimes, not a few companies are less concerned about this. They consider product quality much more important. As good as the quality of the product offered, without good service, consumers will not be interested to buy the product. It could be that consumers will buy products from other companies that have quality products not much different but have a very satisfactory service quality.

One of the service industries that continues to grow today is the air transportation industry. The development of air transportation industry in Indonesia can not be separated from the evolution of aviation industry globally. The phenomenon of the growth of private airlines in Indonesia based on Low Cost Carrier (LCC) began in early 2000, where government regulation allowed private companies to build new airlines with a minimum of 2 fleet of commercial aircraft. Because the LCC-based airline is growing rapidly. 
One of the service industries that continues to grow today is the air transportation industry. The development of air transportation industry in Indonesia cannot be separated from the evolution of aviation industry globally. The phenomenon of the growth of private airlines in Indonesia based on Low Cost Carrier (LCC) began in early 2000, where government regulation allowed private companies to build new airlines with a minimum of 2 fleets of commercial aircrafts. Because the LCC-based airline is growing rapidly.

The increasing number of air passenger passengers in Indonesia as well as the increasingly fierce competition with the emergence of new airlines indirectly affect the quality of service that the LCC airline can deliver to its customers. Until now, there are still many complaints of LCC airline customers we hear with diverse issues ranging from very long and poorly organized check-in queues, frequent delays, unfriendly cabin crew, poor cabin conditions, to baggage of passengers in cargo carried to another destination. This study was conducted with the objectives of exploring:

1. How is the quality of service provided by the LCC airline to its customers?

2. What is the effort made by LCC airline to improve its service quality?

\section{LITERATURE REVIEW}

\section{A. Service Quality}

Gronroos (1991) states that the quality of good service will occur if the quality of services expected by the consumer (expected quality) in accordance with what has been perceived or perceived quality after using the service. In the first aspect (expected quality) there are several factors that influence the aspect to a service. The first is Word of Mouth (WOM). WOM is the most dominant factor in influencing consumer expectations. It generally takes the form of recommendations or suggestions among individuals within a social group. The second factor is personal needs. This factor varies greatly on every individual and there are so many things that affect it. The third factor is past experience where there is a tendency of customers who are experienced in using a similar service to have lower expectations. The last factor is external communication. This factor is generally created by service providers in the form of messages to prospective customers formed in marketing communications such as electronic media advertising, brochures and so forth (Zeithaml et.al.,1990).

Top of Form Providing excellent service quality is widely recognised as a critical business requirement (Voss et al, 2004; Vilares \& Coehlo, 2003; Van der Weile et al, 2002). It is 'not just a corporate offering, but a competitive weapon' (Rosen et al, 2003) which is 'essential to corporate profitability and survival' (Newman \& Cowling, 1996). arasuraman et. al (1985) and Zeithaml et., al (1990) noticed that the key methodology for the achievement and survival of any business foundation is the liberation of value service quality to customers. The nature of service quality offered will decide customer satisfaction.

\section{1) Definitions of Service Quality}

Quality is a multi-dimensional phenomenon. Along these lines, achieving the service quality without recognizing the significant parts of value is unthinkable. In his exchange of administration quality, Gronroos (2000) alludes to three components of yield specialized quality, administration execution quality, and association's psychological picture.

According to Parasuraman et al. (1988), service quality can be characterized as a general judgment like frame of mind towards the administration and by and large acknowledged as a forerunner of in general consumer loyalty (Zeithaml and Bitner, 2003). Parasuraman et al. (1988) have characterized service quality as the capacity of the association to meet or surpass customers desires. It is the contrast, between client desires for administration and saw administration (Zeithaml et al., 1990). Seen administration quality outcomes from correlations by clients of desires with their view of administration conveyed by the providers (Zeithaml et al., 1990). On the off chance that desires are more noteworthy than execution, at that point apparent quality is not exactly attractive and subsequently client disappointment happens (Parasuraman et al., 1985; Lewis and Mitchell, 1990).

Parasuraman et al. (1988) argued that service quality is too high or the fulfillment of customer expectations. This is a gap between services received with the expectation of these services (Zeithaml et al., 1990). The acquisition of perceptions of service quality is a comparison of customer expectations with services provided by suppliers (Zeithaml et al., 1990). If expectations are greater than performance, the perceived quality is unsatisfactory so that customer dissatisfaction occurs (Parasuraman et al., 1985; Lewis and Mitchell, 1990).

Lehtinen and Lehtinen (1982) have referred to dimensions of physical quality, interactive quality, and organizational quality as three dimensions of service quality. The service quality model of Parasuraman et al. (1988) and Zeithaml (1990) suggested a five dimensional structure of perceived service quality tangibles, reliability, responsiveness, empathy and assurance as the instruments for measuring the service quality.

Table 1: Five Broad Dimensions of Service Quality

\begin{tabular}{|c|c|c|}
\hline No & Dimension & Definition \\
\hline 1 & Tangibles & $\begin{array}{l}\text { Appearance of } \\
\text { physical } \\
\text { facilities, } \\
\text { equipment, } \\
\text { personnel and } \\
\text { written materials }\end{array}$ \\
\hline 2 & Reliability & $\begin{array}{l}\text { Ability to } \\
\text { perform the } \\
\text { promised service } \\
\text { dependably and } \\
\text { accurately }\end{array}$ \\
\hline
\end{tabular}




\begin{tabular}{|c|c|c|}
\hline 3 & Responsiveness & $\begin{array}{l}\text { Willingness } \\
\text { customers help } \\
\text { provide } \\
\text { service }\end{array}$ \\
\hline 4 & Assurance & $\begin{array}{l}\text { (including } \\
\text { competence, } \\
\text { courtesy, } \\
\text { credibility and } \\
\text { security) } \\
\text { Knowledge and } \\
\text { courtesy of } \\
\text { employees and } \\
\text { their ability to } \\
\text { inspire trust and } \\
\text { confidence. }\end{array}$ \\
\hline 5 & Empathy & $\begin{array}{l}\text { Caring, easy } \\
\text { access, good } \\
\text { /communication, } \\
\text { customer } \\
\text { understanding } \\
\text { and } \\
\text { individualized } \\
\text { attention given } \\
\text { to cutomers }\end{array}$ \\
\hline
\end{tabular}

Source: Adapted from Zeithaml et al. (1990)

The tangibles include the organizations' agents, physical offices, materials, and gear just as correspondence materials. Besides, Physical ecological conditions showed up as a reasonable proof of the consideration and consideration paid for the subtleties offered by the specialist organization (Fitzsimmons and Fitzsimmons, 2001). Unwavering quality relies upon dealing with client administration issues, plays out the administrations right the first run through; offers benefits on schedule, and keep up a record of blunder free. Besides, they characterize unwavering quality as the most critical factor in regular administration (Parasuraman et al., 1988). Responsiveness is characterized as "the readiness to support clients and give brief service"(Parasuraman et al., 1988). Moreover, Johnston (1997) characterizes responsiveness, for example, speed and practicality of administration conveyance. This comprises of preparing pace and administration capacities to react quickly to client administration demands, and hold up a short and lining time. All the more explicitly, responsiveness is characterized as the eagerness or availability of representatives to give administrations. It contains the practicality of administration (Parasuraman et al., 1985). Parasuraman et al. (1985) characterized sympathy as a minding and individual consideration that the firm gives to its customers. It contains giving individual regard for workers who comprehend the requirements of their clients and client offices during business hours. Moreover, Ananth et al. (2011) exhibits sympathy in their examination of private division banks, give singular consideration and simple task time; give individual consideration, and comprehend the particular needs of clients. Fitzsimmons and Fitzsimmons (2001) propose that compassion contains agreeability, affectability, and endeavors to comprehend client needs. Security is resulted when the administration winds up safe, and the client data gets assurance (Parasuraman et al., 2005; Zeithaml et al., 2002).

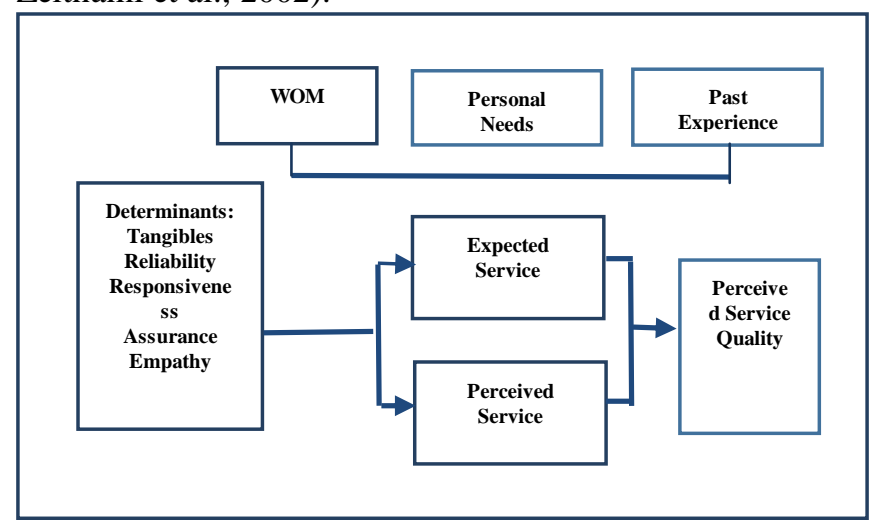

Source : Parasuraman (1988) \& Zeithaml et.al. (1990)

Fig 1. Scheme of Service Quality

\section{2) Service In Airline Companies}

In general, there are two types of services provided by an airline to its passengers (Azmarani, 2016), ie service on land or commonly known as ground handling pax and in-flight service. Ground handling service is a service provided by an airline to its passengers on land or in other words before entering and after leaving the plane. The ground handling service is divided into two namely the departure section consisting of check in, document clearance, baggage handling, load and balance, boarding and arrival section consisting of baggage handling, lost and found, document clearance. In-flight service covers the cleanliness of the airplane toilets, the accuracy of scheduled departures and arrivals, and the service of the cabin crew. Overall, those are the services provided by an airline to its passengers. The consumer's preference for air transportation is increasing every year. In addition to the views of the increase in the number of passengers, it is also reviewed from several things such as increasing customer satisfaction of the airline and customer satisfaction of the airport.

Regulation of aviation in Indonesia according to the Regulation of Director General of Civil Aviation SKEP 87/5/2010 classifies air transport services into 3 types, namely: services with maximum standards (full services), services with medium standards (medium services), and services with minimum standards (no frills). Maximum service standards have the following characteristics: 1) the cost calculation is based on the total cost of the flight operation including the service charge to the service user; 2) the maximum baggage policy of $20 \mathrm{~kg}$ free of charge; 3) the complete available flight services are food, reading materials, entertainment (audio / video), 4) providing more than one class (economic and non-economic classes) and physically separated service groups, 5) executive lounge facilities for certain class passengers, 6) passenger seating distance of more than 29 inches and less than 31 inches. While the medium service standards have the following characteristics: 1) the cost calculation is based on the minimum total cost of flight operation, 
excluding services provided to the users of air freight services, 2) enforcement of baggage fees, 3) unavailable in-flight services, 4) there is only one class of service (economy class), 5) executive lounge facilities for certain class passengers, 6) the distance between seats is more than 29 inches and less than 31 inches. While the minimum service standards have the following characteristics: 1) the cost calculation is based on the minimum flight operating costs, excluding services provided to the users of air freight services, 2) enforcement of baggage fees, 3) unavailable in-flight services, 4) there is only one class of service (economy class), 5) the distance between seats is less than or equal to 29 inches.

Human resources in airlines, especially officers in in-flight service or flight attendants are required to have reliability in various things, especially in terms of safety and security. These include intrapersonal expertise, co-production skills (customer training), non-verbal communication skills, and self-monitoring skills (Wathern \& Anderson, 1995). Youseff (1993) found that companies that adopt and implement computer-based technologies have a higher degree of flexibility than firms that do not adopt. Self check in machines are categorized in hard technology. Hard technology includes technology-based equipment and manufacturing technology. Computer-based technology represents technology-based hardware in the design, fabrication, and administration of all activities necessary to produce products or services (Zammuto and O' Connor, 1992).

\section{B. Customer Satisfaction}

Satisfying customers is one of the main objectives of every business. Businesses recognize that keeping current customers is more profitable than having to win new ones to replace those lost. Management and marketing theorists underscore the importance of customer satisfaction for a business's success (McColl-Kennedy \& Schneider, 2000; Reichheld \& Sasser, 1990). Good customer satisfaction has an effect on the profitability of nearly every business.

Customer satisfaction is a key factor in formation of customer's desires for future purchase (Mittal \& Kamakura, 2001). Customer satisfaction means that customer needs, wishes and expectations are met or overcome during the product/service period, giving way to re-purchasing and customer loyalty (Anton, 1996, p. 23). In other words, "customer satisfaction is the assessment of the pre-purchasing expectations from the product, with the results reached after the act of purchasing." (Lemon et al, 2002, p.1). Customer satisfaction has also been defined by another author as the extent to which a product's perceived performance matches a buyer's expectations (Kotler et al., 2002, p. 8).

Satisfaction dimensions are developed from the previously identified requirements. These are the specific components that make up the requirements. For example, if a customer and organizational requirement is for customer service, the satisfaction dimensions may include interactions, timeliness, and responsiveness. These are the clusters that define the requirements (Hayes, 1998).

Consumer satisfaction on services provided by airlines in Indonesia is very influential on how big the level of service quality of an airline. Various services that affect customer satisfaction are the hospitality of all cabin crew, existing physical facilities, flight rates, the timeliness of departure easy access and flight safety (Davis, 2003). A highly satisfied customer according to Kotler (2000, p. 48) will continue his shopping for a long time, buy more as long as the firm produces new products and the existing products are improved, speak of the firm and its products with praise, keep indifferent to the trademarks that are in competition with the products of the firm and does not place the emphasis on the price, and offer the firm suggestions and ideas about products and services. Various activities which are important for understanding and classification of customers are as follows: Proper understanding of population concept, pattern acquisition and distribution preferences, analysis of sensible groups and unique customers who intend to have similar behaviors in a homogeneous pattern, determining needs and attitudes of different customer classifications (Payne,2005, p.35).

Zamazalová (2008) mentions the key factors that affect customer satisfaction and which can be used to measure customer satisfaction. These factors are product (in terms of its quality, availability etc.); price (convenient payment conditions and others); services; distribution; and image of a product. Quality (both perceived and technical) affects customer satisfaction and companies examine that satisfaction and may react to it by innovating products to increase customer satisfaction further. Customer satisfaction can thus be understood as the result of a subjective process - the customer compares his ideas with perceived reality (Anderson et al., 1994).

\section{METHODOLOGY}

This study employs the qualitative approach. Three LCC airlines were chosen as the sites of the study because the are the top three LCC airlines in the country. The selection of the participants was based on the purposive sampling procedures. The sampling included 3 top leaders of the LCC airlines companies, 9 passengers of LCC airlines, and 1 official of the Ministry of Transportation. The interviews were conducted using an interview guide that has been pilot tested by the researcher.

For this research a phenomenological approach was utilized to explore the phenomena of service quality and customer satisfaction. Thus phenomenology is a very appropriate qualitative design because it will elicit real experiences in the process of creating service quality among the LCC of airlines and provide broad perspectives on what the LCC airlines should do to give customer satisfaction. According to Polkinghorne (Creswell, 2008) the study of phenomenology describes the meaning of a life experience to some people about a concept or phenomenon. 
The people involved in dealing with a phenomenon explore the structure of the awareness of human experience.

Triangulation of data was employed in this study in order to increase the validity by using questionnaires. Before the interview and distribution of questionnaires to 30 passengers of the LCC airlines, the author piloted them to two staff, requesting their opinion and modifications were made accordingly.

Data were analyzed manually. Findings were categorized into themes and categories. Data analysis were carried out simultaneously with the data collection phase. Interviews were transcribed verbatim, including pauses, laughs, and other remarks. Data analyses were conducted in three phases: 1. Data reduction 2. Data presentation 3. Verification of the data collected. The researcher read the transcriptions over and over again to observe the patterns of effective leadership that were repeated. Patton (1990) termed this technique as comparative pattern analysis.

\section{DATA ANALYSIS AND RESULTS}

In depth interviews were conducted to 13 participants consist of 3 Top Leaders of LCC Airlines Companies, 9 passengers and 1 official of the Ministry of Transportation. Whereas questionnaires were distributed to 30 passengers of LCC as consumers.

\section{A. Passengers Interview Data}

From the interview with passengers, it is found that there are still many complaints related to services provided by LCC airlines. Analysis is done by referring to Service Quality Dimension from Zeithaml et al. (1990) consisting of: Tangibles, Reliability, Responsiveness, Assurance and Empathy, which are categorized into two types of air services: ground handling and inflight service (Azmarani, 2016).

\section{1) Ground Handling}

\begin{tabular}{|l|l|l|}
\hline No & $\begin{array}{c}\text { Dimensio } \\
\mathrm{n}\end{array}$ & \multicolumn{1}{c|}{$\begin{array}{c}\text { Service Perceived by } \\
\text { Customers }\end{array}$} \\
\hline 1. & Tangibles & $\begin{array}{l}\text { Queues in Check in Counter } \\
\text { often look very long and not } \\
\text { well organized causing the } \\
\text { check in counter area is very } \\
\text { dense and less comfortable. } \\
\text { There is no special queue } \\
\text { line for elderly passengers } \\
\text { and persons with disabilities. } \\
\text { Check in mobile and website } \\
\text { is less efficient because after } \\
\text { doing check in the website or } \\
\text { mobile, passengers who want } \\
\text { to deposit the paid baggage } \\
\text { still have to queue at the } \\
\text { same counter where other } \\
\text { passengers do check in. } \\
\text { The number of self-check-in } \\
\text { machines available at the } \\
\text { airport is also deemed } \\
\text { insufficient and often the } \\
\text { machine is out of order. As a }\end{array}$ \\
\hline
\end{tabular}

\begin{tabular}{|c|c|c|}
\hline & & $\begin{array}{l}\text { result, passengers still have } \\
\text { to queue at the check-in } \\
\text { counter. }\end{array}$ \\
\hline 2. & Reliability & $\begin{array}{l}\text { There are still frequent flight } \\
\text { schedules experiencing delays } \\
\text { with operational reasons that } \\
\text { are not concerned with } \\
\text { passengers as customers. } \\
\text { Passengers also still often } \\
\text { experience loss of luggage in } \\
\text { the suitcase. }\end{array}$ \\
\hline 3. & $\begin{array}{l}\text { Responsiv } \\
\text { eness }\end{array}$ & $\begin{array}{l}\text { Officers at the check in counter } \\
\text { are less responsive and give } \\
\text { too long service so the queues } \\
\text { are often very long. As a result } \\
\text { passengers have to stand a } \\
\text { long time and become panic } \\
\text { because the departure schedule } \\
\text { is getting closer. }\end{array}$ \\
\hline 4. & Assurance & $\begin{array}{l}\text { Officers at ground handling } \\
\text { are less friendly to customers. } \\
\text { Officers also often provide } \\
\text { different answers to } \\
\text { customers questions that } \\
\text { seem less professional and not } \\
\text { well informed. } \\
\text { Faulty procedures performed } \\
\text { by pilots such as landing } \\
\text { aircraft from Singapore in the } \\
\text { domestic flight terminals, } \\
\text { indicating less competent } \\
\text { human resources at LCC } \\
\text { airlines. }\end{array}$ \\
\hline 5. & Empathy & $\begin{array}{l}\text { Officers at ground } \\
\text { handling are incapable to } \\
\text { communicate well, so } \\
\text { they give impression of } \\
\text { unfriendliness and } \\
\text { unwilling to understand } \\
\text { the wishes of customers. } \\
\text { Officers are also less } \\
\text { sensitive to elderly } \\
\text { customers and persons } \\
\text { with disabilities. }\end{array}$ \\
\hline
\end{tabular}




\section{2) Inflight Service}

\begin{tabular}{|c|c|c|}
\hline No & Dimension & $\begin{array}{l}\text { Service Perceived by } \\
\text { Customers }\end{array}$ \\
\hline 1. & Tangibles & $\begin{array}{l}\text { The cleanliness of the } \\
\text { cabin toilets seemed } \\
\text { less noticeable. } \\
\text { The carpet inside the } \\
\text { cabin looks dull and } \\
\text { dirty. } \\
\text { The seat belt straps } \\
\text { look dirty. } \\
\text { The magazines } \\
\text { provided on every seat } \\
\text { are dull and torn. } \\
\text { The glass windows } \\
\text { look dull and dirty. }\end{array}$ \\
\hline 2. & Reliability & $\begin{array}{l}\text { In terms of the facilities } \\
\text { provided and the services } \\
\text { offered, the LCC is unable } \\
\text { to fulfill what is promised } \\
\text { in the advertisements. }\end{array}$ \\
\hline 3. & Responsiveness & $\begin{array}{l}\text { Cabin crew only see and } \\
\text { supervise it without } \\
\text { providing assistance when } \\
\text { passengers have difficulty } \\
\text { entering their goods into } \\
\text { the trunk above the cabin. } \\
\text { Cabin officers are also less } \\
\text { responsive to serving } \\
\text { elderly passengers and } \\
\text { persons with disabilities }\end{array}$ \\
\hline 4. & Assurance & $\begin{array}{l}\text { Cabin Crew on the plane } \\
\text { are less friendly to } \\
\text { passengers } \\
\text { The aircraft condition and } \\
\text { the performance of officers } \\
\text { at the airline provide a } \\
\text { sense of security for the } \\
\text { customers. }\end{array}$ \\
\hline 5. & Empathy & $\begin{array}{l}\text { Cabin Crew are not skillful } \\
\text { to treat passengers with } \\
\text { children. } \\
\text { Officers do not pay proper } \\
\text { attention to passengers with } \\
\text { disabilities. }\end{array}$ \\
\hline
\end{tabular}

\section{B. Top Leaders Of LCC's Data}

From the interview with the top leaders of LCC airlines companies, it is found that excellent service is the most important factor that should be done by every airline. Strategies undertaken by LCC airlines in Indonesia to improve the quality of service are:

\section{1) Tangibles}

Various efforts have been made to facilitate customers in check- in procedure. By check-in through the website or check-in independently through self check-in-machine with hard technology at the airport. This is done to reduce the queue at the conventional check-in counter so that customers will feel more comfortable.

\section{2) Responsiveness}

To deal with and handle the delay, the LCC is guided by the regulation of Minister of Transportation No. 89 of 2015 so that it refers to the ability of the delay management. All LCC airlines must be able to get ISO 9001: 2015 certification from British Standard Institute (BSI). The responsiveness of the airlines and its human resources can both realize the fulfillment of customer rights when a delay occurs. An example of an airline responsiveness is to notify passengers in case of delay along with factors causing such delays by direct announcement (if delay occurs suddenly when passengers are in the waiting room), via SMS and e-mail. The officer informs the passengers about how long the delay takes. Therefore, that kind of information is what the customer needs. That way, passengers will feel comfortable and trust. The human resources who are in the pre-flight stage should provide good competence of responsiveness and be able to recognize the needs and desires of passengers. Similarly, the officers who are in the process of in-fligth and post-flight should be able to provide services in a maximum standard of services. Good service will provide satisfaction for customers and satisfied customers will become loyal customers because there will be repeated purchases.

\section{3) Reliability}

Every airline has made efforts to be able to deliver its services right on the first time, fulfilling its promise accurately and reliably (for example, delivering services in accordance with agreed schedule), keeping records accurately, and submitting bills accurate. Officers in-flight service namely stewardesses have an important role in providing services to passengers during the in-flight process. Therefore, an airline always demands the stewardesses to have reliability in various things, especially in terms of safety and security. The flight attendants face and provide services directly to passengers, therefore they have a high contact with passengers or customers. This includes intrapersonal expertise, co-production skills (customer training), non-verbal communication skills, and self-monitoring expertise.

\section{4) Assurance}

Efforts made by airlines is to provide assurance in the form of crew's behavior which is able to grow customers' confidence to the company and the company can create a sense of security for its customers. Assurance also means that airline crew are required to always be polite and master the knowledge and skills required to handle any customers' questions or concerns. In that case, the LCC airline claims to have obeyed PM 89 of 2015. 
In addition, in terms of cost certainty, the LCC airline claims to have complied with the upper and lower border rules as stipulated by the Minister of Transportation Regulation of the Republic of Indonesia (KM 26 of 2010). For that reason, although passengers buy tickets from various places, the price range of the tickets are the same. In addition, tickets are also included in the cost of airport tax or Passenger Service Charge (PSC). Therefore, passengers will be easier to make payments and reduce the check point at the airport so ineffectiveness can be avoided. The LCC airlines also claim to have guaranteed the claims of damage or loss of baggage at Lost and Found counter at each airport. Thus, passengers will feel safe while using the services of LCC.

\section{5) Empathy}

Another effort is to improve the interpersonal communication skills of the crew by prioritizing the customer's interests, understanding customers with a friendly attitude and courtesy, serving with respect and non-discrimination. LCC crew also must try to meet the desires of different passengers. The LCC crew have to pay special attention to special needs passengers, namely the elderly, children and the disabled. An empathetic attitude should be shown by the officer by providing convenience to the passenger category. Associated with the competence of human resources, the number of employees of the LCC airlines is currently still dominated by senior high school graduates. However, there has been changes in recruitment system now since majority of airlines companies have recruited quite many university graduates. The higher educational background shows that employees should be able to understand the performance and job description of each in serving the passengers. The standard of education also varies for each position. At present, to improve the quality of LCC services, airlines also provide training for employees from top level to the lowest.

\section{Government's Data}

From the interview with the official of the Ministry of Transportation, it is found that: Low cost carrier is an airline that operates efficiently to achieve the lowest possible cost for products offered but still consistent with integrity and operational safety. Good service quality will affect the level of customer satisfaction. Consumers who are satisfied with the services provided by an airline will then continue to buy the tickets sold by the airline. Unfortunately there are still many airlines fail to maintain the customer loyalty. The failure is generally due to not being able to maintain the consistency of the quality provided. This seems to be the case in most airlines in Indonesia.

Low operational costs can be realized among other things because the service during flights does not include dish, easy and cheap ticket booking (via internet or call center), the use of one type of aircraft to speed up turnaround time and simplify maintenance, many reach out to secondary airports that are cheaply costing. However, since the airline provides a low cost, indirectly it reduces the revenue to be received by the airline. Therefore, the LCC airlines also have to cut some operational cost of company. This gives a bad impact because the airlines then anticipate by reducing the aircraft fuel. The aircraft fuel is completely fitted for the route, so it makes the pilots try to make the fuel rudiment really able to get the plane to the destination.

This makes the flight dangerous because sometimes it passes through a path that should not be passed by the aircraft so that it can allow an accident. In addition, because of low income, airlines then anticipate by reducing the cost of aircraft maintenance so that the aircraft used rarely get treatment. Overall the average airlines in Indonesia provide a low tariff by eliminating some services.

Although many LCC airlines today offer low rates, good safety and service are essential. However, in reality the low price actually makes the airline put aside the level of safety and good service. The Government periodically supervises the LCC's airlines. Several sanctions have been imposed on airlines that do not comply with government regulations such as the case of faulty flight landing procedures from abroad that should land at the international terminal, but land on domestic terminals so that passengers of foreign nationals were barely passing the immigration checks. This happened because the LCC pilots were not subject to Air Traffic Control (ATC) rules and the Ministerial Regulation No. 61 of 2015 on Air Facilitation (FAL). In the regulation, it is mentioned that the handling of aircraft parking including passenger transport to immigration check is the responsibility of the airlines.

The case of abandonment of passengers has been regulated in the Minister of Transportation Regulation No. 77 on Responsibility of Air Transportation but no sanctions if negligent. Therefore, the Ministry of Transportation will make more stringent regulations so as to provide a deterrent effect for airlines who neglect to serve passengers. The airline is only required to provide compensation. If the passengers are not satisfied then they can bring a civil court to the concerned airline.

Article 9 of Minister of Transportation Regulation No. 77 regulates the matters of flight delay, non-conveyance passengers by reason of full capacity and flight cancellation. The amount of compensation for passengers is Rp 300,000 if it is over 4 hours late. Rp 150.000 if the airline offers another route closest to the final passenger flight destination in which flight tickets should be provided by the airline. Article 11 stipulates that if there is a case of non-conveyance of passengers, the airline shall indemnify in the form of transferring to another flight without paying additional fees or providing consumption, accommodation and transportation costs in the absence of other flights to the destination. Article 12 provides for flight cancellations, in which the carrier shall notify the passenger no later than 7 calendar days prior to the flight. The carrier is obligated to refund all the tickets that the passenger has paid. There are 5 stages to stop the operation of airlines, the warning of 1 to 3 , suspend, then dismissed its operating license.

To improve the level of aviation security in Indonesia, the Ministry of Transportation announced the ratings of 
existing airlines in Indonesia. The ranking is divided into three categories. Category I indicates that the airlines that fall into this category really meet the passenger safety level. Category II indicates that the airline has met the minimum requirements of aviation safety, but there are still some requirements that have not been fulfilled. And Category III indicates that the airline has met the minimum requirements of flight safety but there are still some requirements that have not been implemented thus reducing the flight safety level. Of the 20 airlines assessed, none of which included in category I. A total of 13 of them included in category II and the remaining 7 included in category III.

\section{Questionnaires Data}

From the questionnaires distributed to 30 LCC passengers, it is found that consumers are still not satisfied especially with flight schedules which until now still experience delays due to operational reasons. In addition, hospitality from the officers both in ground handling and in-flight service has not been obtained by consumers. LCC consumers seem to be less concerned about the condition of the aircraft even though it is closely related to the safety. We can see many airlines in Indonesia are still using old or used aircrafts and looks less well maintained. The service at the check-in counter also still seems slow and make long queues, Similarly, the baggage collection is long and sometimes found damaged.

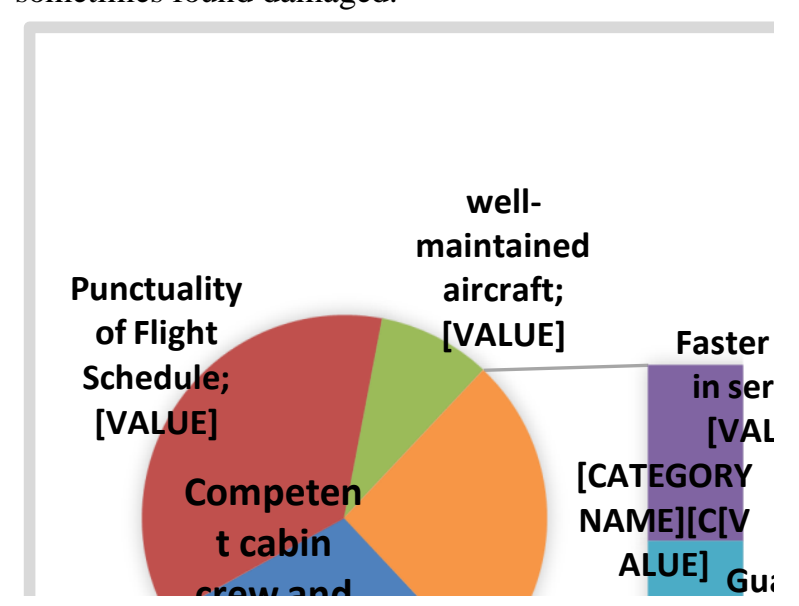

Fig 1. The most important factors to be improved in LCC services

\section{DISCUSSION}

From this research, it is known that there are still many complaints submitted by consumers in this case passengers or prospective passengers to the LCC. The human resource factors in the five dimensions of service quality are Tangibles, Reliability, Responsiveness, Assurance, Empathy (Parasuraman et al., 1988 and Zeithaml 1990) need to be improved because service quality is the ability of the organization to meet or exceed customer expectations. This conforms the statement of Parasuraman et al. (1988). The dimension of service quality is closely related to human resources factors.

From the data analysis, it was found that training for human resources in airlines is very necessary. These include intrapersonal expertise, co-production skills (customer training), non-verbal communication skills, and self-monitoring skills (Wathern \& Anderson, 1995). Although to face and handle the delay, LCC airlines already have guidance on PM 89 of 2015 and all LCC airlines are required to get ISO 9001: 2015 certification from British Standard Institute (BSI) but until now it has not been running as expected. There are still many complaints addressed by consumers regarding delay issues and changing schedules of flight departure. This indicates that the existing guidelines have not been implemented well.

This research also found that the use of computer technology in the administration of aviation greatly supports the speed and accuracy in service. This is one of the efforts implemented by LCC airlines to improve the quality of service as stated by Youseff (1993) that companies which adopt computer-based technology have a higher degree of flexibility than companies that do not adopt.

The research also found that there is a lack of synchronization in the effort to improve the quality of services and policies. In one hand, the government requires all airlines to make improvements in some aspects, especially the problem of the punctuality of flight schedule, but on the other hand the Minister of Transportation Regulation No. 77 does not include sanctions for airlines that neglect passengers. The airline is only required to provide compensation. If the passengers are not satisfied then they can bring a civil court to the concerned airline.

\section{CONCLUSION}

This research shows that until now consumer complaints against LCC airlines are still very high, not only because of problems found on land but also when consumers are in the air. This research reveals that all airlines that run the LCC concept must make improvements in various matters related to the service that leads to customer satisfaction. In addition to the company, the government should also take more strict supervision to the LCC organizers and re-evaluate the existing policies mainly related to sanctions for airlines that do not obey the set regulation.

\section{REFERENCES}

[1] Azmarani, Adinda Wahyu. (2016). Analisis Kualitas Pelayanan Maskapai Penerbangan Low Cost Carrier (Studi Deskriptif Di PT. Citilink Indonesia Cabang Surabaya). Kebijakan dan Manajemen Publik, Volume 4, Nomor 3, September - Desember 2016.

[2] Alipour, Mehrdad and Mohammadi, Mohammad Hallaj (2011). The Effect Of Customer Relationship Management (CRM) On Achieving Competitive Advantage Of Manufacturing Tractor. Global Journal of Management and Business Research, Volume 11 Issue 5 Version 1.0 April 2011.

[3] Ananth, A., Ramesh, R. and Prabaharan, B. (2011), Service Quality GAP Analysis in Private Sector Banks A Customer Perspective, Internationally Indexed Journal, Vol. II, Issue. 1 pp., 245-252.

[4] Anderson, E. W., Formelo, C., Lehmann, D. R. (1994). Customer Satisfaction, Market Share, and Profitability: Findings from Sweden. Journal of Marketing, Vol. 58, No. 3, p. 53-66.

[5] Anton, J. (1996). Customer Relationship Management: Making Hard Decisions with Soft Numbers, Upper Saddle River, Prentice-Hall. 
[6] Creswell, J. W. (2008). Educational research: Planning, conducting, and evaluating quantitative and qualitative research (3rd ed.). Upper Saddle River, NJ: Pearson

[7] Creswell, J. W. (2014). Research design : qualitative, quantitative, and mixed methods. Retrieved from http://pustakapelajar.co.id/buku/research-design-pendekatan-kualitatifkuantitatif-dan-mixed/

[8] Scott R. Swanson, J., Charlene, Davis. (2003) The relationship of differential loci with perceived quality and behavioral intentions, Journal of Services Marketing, Vol. 17 Issue: 2, pp.202-219, https://doi.org/10.1108/08876040310467943

[9] Fitzsimmons, Jams, A \& Fitzsimmons, Mona, J. ( 2001). Service Management : Operating Strategy and Information Technology. New York, London : McGraw Hill

[10] Gilaninia, S., Shafiei, B., \& Shadab R. (2013). The Effect of Internal Marketing on Customer Orientation. Universal Journal of Management and Social Sciences, Vol. 3, No.11.

[11] Gronroos (1991). The Marketing Strategy Continuum: Towards a Marketing Concept for the 1990s. Management Decision, Vol. 29 Issue: 1, https://doi.org/10.1108/00251749110139106

[12] Gronroos, C. (2000). Service Management and Marketing. John Wiley \& sons Ltd.

[13] Hayes, B. (1998). Measuring Customer Satisfaction. Milwaukee, WI: ASQ Quality Press.

[14] ISO 9001: 2015 Certification from British Standard Institute (BSI)

[15] Lehtinen, U., \& Lehtinen, J.R. (1982). Service quality- a study of dimensions. Unpublished working paper, Service Management Institute, Helsinki, 439-460.

[16] Johnston, R. (1997). Identify the critical determinants of service quality in retail banking: Importance and Effect. International Journal of Bank Marketing, 15(4), 111-116.

[17] Kotler, Philip and Andreasen, Alan. (2002). Strategic Marketing for Nonprofit Organizations. Prentice Hall, 6th edition.

[18] Kotler, Philip (2000). Marketing Management Millenium Edition, Tenth Edition, Prentice-Hall, Inc.

[19] Layton, A. P., and G. H. Moore (1989). Leading Indicators for the Service Sector. Journal of Business and Economic Statistics, 7 (3, July), 379-386.

[20] Lemon, Katherine N., White, Tiffany Barnett, \& Winer, Russeil S Winer (2002). Dynamic Customer Relationship Management : Incorporating Future Considerations Into the Service Retention Decision. Journal of Marketing, Vol. 66, January, 1-14.

[21] Lewis, B.R. \& Mitchell, V.W. (1990). Defining and measuring the quality of customer service, Marketing Intelligence and Planning, Vol. 8(6), p.11-17.

[22] McColl-Kennedy, J., \& Schneider, U. (2000). Measuring Customer Satisfaction Why, What and How Total Quality Management, 11, 883-889.

[23] Minister of Transportation Regulation. Decree Number : PM. 89 of 2015 on flight delay management on Commercial Air Transport Agency in Indonesia. Jakarta: Ministry of Transportation of Republic of Indonesia

[24] Minister of Transportation Regulation. Decree Number KM 26 of 2010 on Formulation Mechanism of Calculation And Stipulation Of Rate Limit For Passenger Of Economic Class of Domestic Air Transportation. Jakarta: Ministry of Transportation of Republic of Indonesia

[25] Minister of Transportation Regulation. Decree Number 61 of 2015 on Air Facilitation (FAL). Jakarta: Ministry of Transportation of Republic of Indonesia.

[26] Minister of Transportation Regulation. Decree Number 77 of 2011 on Responsibility of Air Transportation. Jakarta : Ministry of Transportation of Republic of Indonesia.

[27] Mittal, V. \& Kamakura W.A. (2001, February). Satisfaction, repurchase intent, and repurchase behavior: investigating the moderating effect of customer characteristics. Journal of Marketing Research, 38, 131-142.

[28] Nejadjavad, Maryam, Gilaninia, Shahram. (2016). Assessing The Impact Of Service Quality On Customer. Loyalty Using Model Enhanced of Kitapci. Arabian Journal of Business and Management Review (OMAN Chapter). Vol. 5, No.6; January 2016.

[29] Newman, K. and Cowling, A. (1996), Service quality in retail banking: the experience of two British clearing banks. International Journal of Bank Marketing. Vol. 14, No. 6 pp. 3-11

[30] Parasuranam, A. Zeithmal, V. A. Berry, L. L. (1985). A conceptual model of service quality and its implications for future research. Journal of Marketing, Vol. 49, Fall, pp. $41-50$

[31] Parasuraman, A., Zeithaml, V. \& Berry, L (1988). SERVQUAL: A multiple item scale for measuring customer perceptions of service quality. Journal of Retailing, 64(1), 12-40.
[32] Parasuraman, A., Zeithaml, V.A. and Malhotra, A. (2005) E-S-Qual-A Multiple Item Scale for Assessing Electronic Service Quality. Journal of Marketing, 7, 213-233.

[33] Patton, M. (1990). Qualitative evaluation and research methods. (pp. 169-186). Beverly Hills, CA: Sage.

[34] Payne, A. and Frow, P. (2005). A Strategic Framework for Customer Relationship Management, Journal of Marketing, (69:4):167-191.

[35] Regulation of Director General of Civil Aviation SKEP 87/5/2010

[36] Reichheld, F.F. \& Sasser, Jr., W.E. (1990). Zero defections. Quality comes to services. Harvard Business Review, 68(5), 105-111.

[37] Rosen, L. D. Karwan, K.R. Scribner, L.L. (2003), Service quality measurement and the disconfirmation model: taking care in interpretation. Total Quality Management, Vol. 14, No. 1, pp.314.

[38] Schneider, B. \& Bowen, D. (1985). Employee and customer perceptions of services in banks: replication and extension. Journal of Applied Psychology, Vol. 70, p. 423-433

[39] Spohrer, J. and. Maglio, P.P. (2008). The Emergence of Service Science: Toward Systematic Service Innovations to Accelerate Co-Creation of Value. IBM Almaden Research Center.

[40] Surprenant and Solomon (1987) Surprenant, C.F. \& Solomon, M.R. (1987). Predictability and Personalization in the Service Encounter. Journal of Marketing, Vol. 51, p. 86-96

[41] Van der Weile, Ton, Van Iwaarden, Jos (2002). A Study on the Applicability of Servqual Dimensions of Web Sites. ERIM Report Series Reference No. ERS-2002-61-ORG. Erasmus Research Institute of Management (ERIM). Erasmus Universiteit Rotterdam.

[42] Vilares \& Coehlo, 2003; Vilares, M.J. and Coehlo, P.S. (2003), The employee-customer satisfaction chain in the ESCI model. European Journal of Marketing, Vol. 37, No. 11/12, pp. 1703-1722.

[43] Voss, C. Roth, A.V. Rosenzweig, E.D. Blackmon, K. Chase, R.B. (2004), 'A Tale of Two Countries' Conservatism, Service Quality, and Feedback on Customer Satisfaction', Journal of Service Research, Vol 6, No 3 pp. 212-23.

[44] Wathen, Samuel and. Anderson, John, C. (1995). Designing services: an information-processing approach. International Journal of Service Industry Management, Vol. 6 Issue: 1, pp.64-76,

[45] Youssef, Mohammad, A.(1993). Computer-based technologies and their impact on manufacturing flexibility. International Journal of Technology Management, $\mathrm{Vol}$, Issue 3-5.

[46] Zammuto, R. F., \& O'Connor, E. J. (1992). Gaining advanced manufacturing technology's benefits: the roles of organization design and culture. Academy of Management Review, 17, 701-728.

[47] Zamazalová, M. (2008). Spokojenost zákazníka. Acta Oeconomica Pragensia, Vol. 16, No. 4, p. 76-82.

[48] Zeithaml, V.A., \& Bitner,M.J. (2003). Services Marketing, Integrating Customer Focus across the Firm. New York: McGraw-Hill.

[49] Zeithaml, Valerie A., Parasuraman, A. \& Berry, Leonard L. (1990) Delivering Quality Service. The Free Press, New York, N.Y.

[50] Zeithaml, V.A, Parasuraman, and Malhotra, A. (2002). Service quality delivery through web sites: A critical review of extant knowledge. Journal of the Academy of Marketing Science, Vol. 30 No. 4, pp. 362-375.

\section{AUTHOR PROFILE}

Resista Vikaliana

Currently I am affiliated with Department Logistics Management, Institut Ilmu Sosial dan Manajemen Stiami, Jakarta, 10530, Indonesia and my area of research is Social sciences.

\section{Yuli Evitha}

I am affiliated with Department Logistics Management, Institut Ilmu Sosial dan Manajemen Stiami, Jakarta, 10530, Indonesia my area of research social sciences. 